\title{
COMING TOGETHER BUT STAYING APART: CONTINUITY AND CHANGE IN THE AUSTRIAN AND SWISS VARIETIES OF CAPITALISM
}

\author{
Alexandre Afonso, European University Institute, Florence \\ André Mach, University of Lausanne
}

\section{INTRODUCTION ${ }^{1}$}

Austria and Switzerland are two small open European economies that share many similarities but also significant differences in their structures of economic governance. Both can be considered corporatist since major aspects of economic regulation rely upon a system of organised cooperation between labour and capital, but their respective position on the "liberal" and "statist" axis (Becker, this volume) vary to an important extent. On the one hand, Austria and Switzerland have most commonly been classified as political economies where cooperation between economic actors has prevailed over arms-length competition. According to Katzenstein $(1984 ; 1985)$, the dual strategy of external laissez-faire and domestic interventionism pursued by small European states was made possible by the co-operative stance prevailing among political and economic elites. Similarly, in the "Varieties of Capitalism" approach (Hall \& Soskice 2001), both countries are classified among coordinated market economies (CMEs), where non-market mechanisms of coordination play a crucial role in the setup of relations between economic actors: highly coordinated industrial relations and corporatist institutions (Katzenstein 1985), a high degree of cartelisation in the domestic product market (Schröter 1999), and in the rules governing corporate governance (David \& Mach 2004). In this perspective, both Austria and Switzerland are good examples of political economies where cooperative mechanisms of coordination have played a central role in the organisation of production processes.

On the other hand, the Austrian and Swiss political economies also display important differences in their underlying institutional arrangements and power relationships. Most importantly, market mechanisms and private solutions have played a more privileged role in Switzerland than in Austria, where political control over the economy has been greater. Along this latter line, Katzenstein (1984; 1985) already made a distinction between the liberal variant (Switzerland, the Netherlands and Belgium) and the social variant (Austria, Denmark, Norway) of democratic corporatism. These two variants differed in the respective strength of employer and labour organisations. Switzerland was considered the most liberal example, with weak trade unions, well organised and strongly export-oriented employers, and essentially private adaptation strategies designed within 
strongly cohesive business organisations. Austria, known for its 'Austro-Keynesianism' combining fiscal, monetary and incomes policy throughout the post-war decades (Scharpf 1991), appeared to be the foremost example of social corporatism, with strong trade unions entertaining close ties with a dominant social-democratic party, weaker business associations dominated by SMEs, and public adaptation strategies. In Austria, the state has traditionally played a predominant role in shaping economic change, notably through an important industrial sector under public control. By contrast, in Switzerland, a much less interventionist central state combined with a powerful coordination potential amongst business interests has been a dominant feature in the organisation of the political economy.

This chapter assesses institutional continuity and change in these two countries. In the face of growing internationalisation, budgetary constraints and European integration, continuity and change have been determined by prevailing interest configurations and institutional limits in terms of public intervention and private governance. Hence, private employer dominance in Switzerland has fostered rapid change in areas where private regulation prevailed, such as corporate governance, whereas institutional veto points have strongly limited change in areas where public intervention was necessary. By contrast, the larger scope of public intervention in Austria and its more majoritarian features have allowed more space for change in welfare reforms while the strong institutionalisation of corporatist institutions in labour market governance, for instance, has made it more resilient to change than Switzerland. In this respect, Austria and Switzerland provide good examples of how institutional change is dependent on the respective share of public regulation and private governance.

This chapter is structured as follows. We first briefly outline economic performance and macro-institutional frameworks in both countries. The next sections assess the dynamics of continuity and change in the different spheres of their political economies: corporate governance and economic regulation, labour market and industrial relations, and the welfare state. For each sphere, we assess the extent and type of change in a comparative perspective.

\section{PERFORMANCE AND INSTITUTIONAL REGIME}

Austria and Switzerland have displayed fairly similar positive results in terms of macroeconomic performance (see Table 1). Besides high employment ratios, especially for Switzerland, unemployment has never exceeded five percent during the last thirty years. In the case of Switzerland, economic growth remained modest during the 1990s in comparison with other European countries (for more details see Bonoli \& Mach 2000; Hemerijck et al. 2000; Merrien \& Becker 2005). By contrast, this was compensated to some extent in Austria by its entry into the EU in 1995 and the opening of new markets in Central and SouthEastern Europe. Concerning their employment structure, the proportion of 
industrial jobs has declined but remains above the OECD average. Both economies also became much more dependent on their external economic environment with a steady increase in the share of exports in percent of GDP and the increasing importance of outward foreign direct investment, particularly in the Swiss case (see Table 2 below).

\section{- Table 1 about here -}

Structuring factors in political economies can be grasped through the macroinstitutional regime - the political system and the main political players including those of capital and labour - and the sectoral regimes governing specific spheres such as corporate governance, industrial relations, and the welfare state. The first factor strongly determines the level of public intervention and tri-partite corporatism possible in a political economy. Austria and Switzerland are very different in this respect, which accounts to a great extent for the divergent paths of development in their varieties of capitalism. In a nutshell, the differences can be summarised by fragmented state, constrained executive power and bourgeois dominance in Switzerland, and centralised state, stronger executive power and strong labour in Austria. The great number of institutional barriers to state action in Switzerland has fostered extensive private self-regulation strategies in the economic sphere, whereas state intervention and public regulations have played a more important role in Austria. First, both countries are formally federalist, but Swiss cantons enjoy many more competences (in domains such as health/welfare, education, and justice/police) than Austrian Länder, which has limited the potential for centralised macroeconomic management in Switzerland (Lijphart 1999: 189). Second, due to perfect bicameralism and direct democracy, executive power in Switzerland is much more constrained than in Austria, which features a more typical parliamentary democracy with a weak second chamber. Switzerland, by contrast, has been governed by grand coalitions with identical party compositions since 1959. Given the low party discipline, majorities must be built up depending on issues, which pushes governments into constant negotiations with parliamentary factions in a similar fashion to the system in the USA. On top of this, laws are subjected to a referendum if $50^{\prime} 000$ voters request it. In practice, this gives a veto power to any interest group able to gather those signatures. Finally, Austria and Switzerland have diverged significantly with regard to power relations between political forces. While social democracy, for 52 years between 1945 and 2008, has taken part in government on an equal or dominant basis vis-à-vis the right for most of the last 60 years in Austria (Pelinka 2008: 434), Swiss social democrats have always (continuously since 1943) participated on a minority basis in coalitions dominated by centre-right parties. The Swiss labour movement has been structurally weaker because of a number of adverse factors: a decentralised economic structure, the dominance of small 
firms, linguistic and religious cleavages and the continuous presence of a large foreign workforce - about a quarter of the active population - not endowed with electoral rights. At the same time, for its part, Swiss business organised effectively early on under the leadership of export industries, finance and banking. In comparison, Austrian business has historically been weaker, mainly as a result of political alliances favouring the preservation of agriculture and handicraft at the expense of big business, and a large state sector allowing little room for the emergence of private business power (Traxler 1998: 240). These political constellations have strongly conditioned the priorities of policy-making. Austria carried out a form of centralised macroeconomic management ("AustroKeynesianism") until the 1980s. This proved fairly successful to manage the oil shocks, before being progressively abandoned from the 1980s onwards, along with the substantial privatisation of a hitherto large private industrial sector. Over this period, unemployment rose to about five percent and the government started to implement budgetary discipline and to move to partial retrenchment of social benefits (Obinger \& Talos 2009). The choice to join the EU in 1995 accelerated the reforms toward privatisation and liberalisation; it also implied conforming to the Maastricht criteria concerning budgetary policy and prompted a more restrictive financial policy.

By contrast, Switzerland never relied on a Keynesian approach of macroeconomic coordination and has favoured private adaptation strategies instead, thereby illustrating the adjustment pattern of "liberal" corporatism as outlined earlier by Katzenstein. Since the Second World War, Switzerland has notably relied on the massive presence of foreign workers with precarious work permits, that have continuously constituted a significant part of the workforce (from 15 to 25 percent) and allowed for the adjustment of the supply of foreign labour to economic conditions up until the 1990s (Afonso 2005; Fluckiger 1998). Piotet (1987) characterised this pattern of adjustment as "selective corporatism". Foreign and female workers mainly bore the costs of economic downturns, whereas the Swiss male "core" workforce remained rather unaffected. In part because of the degree of flexibility of the labour market, the 1980s did not display substantial policy and economic changes. This changed with the recession of the beginning of the 1990s, which constituted a turning point in the economic evolution of the post-war period (for more details see Bonoli \& Mach 2000; Merrien \& Becker 2005). For the first time since the 1930s, unemployment increased sharply, reaching more than 4 percent in 1994, and public debt, partially due to slow GDP growth, increased. The 1990s were also marked by important debates concerning the Swiss relationship to the EU (rejection of the entry into the European Economic Area in a referendum in 1992). Within this context, the early 1990s saw a shift in the political orientation of the business community, especially its export-oriented sector. The initiative originated within an informal group of representatives of Switzerland's largest companies, along with several neo-liberal academic economists. Switzerland's competitiveness, 
they argued, was endangered by regulations and non-competitive arrangements making products and services too expensive (for more details, see Mach 2006). Even though the group's proposals were not fully implemented, they largely inspired the orientation of the social and economic policy reforms during the 1990 s and 2000s. This constituted the general framework in which the changes in the different spheres of the economy outlined below took place.

\section{CORPORATE GOVERNANCE AND ECONOMIC REGULATION}

The increasing liberalisation of product and financial markets at the international level during the last thirty years has represented a profound change in the economic environment of small European states. Even if they could be expected to be less vulnerable to economic globalisation because of their longstanding integration in world markets, these dynamics nevertheless represented a profound change in the nature of external constraints they had to deal with. They fostered important reforms in the field of corporate governance, and, more generally, in the nature and scope of economic regulation in both countries. Here, we focus our analysis on two dimensions. First, on the reforms of the national corporate governance system in the two countries that plays a crucial role concerning the control and the financing of companies. Second, more broadly on product market regulation, including the liberalisation policies carried out by the two countries during the 1990s.

Whereas Katzenstein (1985) underlined the importance of corporatist institutions and domestic compensation in the strategy of small European states to cope with the pressures of international markets, one can also identify specific characteristics in their corporate governance systems. Two elements are particularly important: the high degree of cohesion of the business community and the combination of free trade policies with elements of 'selective protectionism' (for more details, see David \& Mach 2004). Small European states are generally characterised by dense inter-firm networks, cohesive business elites and the prevalence of regulations designed to preserve national control over large companies in company law and financial rules. This applies fairly well to Austria and Switzerland, even though the instruments whereby this control was exerted were quite different. In the Swiss case, a highly cohesive business community was the major architect of the functioning of the corporate governance system. In Austria by contrast, the control over the largest companies was essentially exercised by the state through state-owned banks and holdings.

Despite its high degree of internationalisation, the Swiss business community has maintained a strong leeway on corporate governance - power of decision, control of shareholding - while leading positions were kept in the hands of Swiss citizens. Three central elements were at the heart of this policy: a high concentration of ownership; a high density of interlocking directorates, especially the close relations between banks and industry; and the existence of 
specific protectionist regulations (laid down in company law) that allowed for the preservation of domestic corporate control in the hands of a small group of insiders (large historical shareholders, managers and bank directors). Switzerland was often dubbed the "fortress of the Alps" by the international financial community (David \& Mach 2004; Schnyder et al. 2005). With the liberalisation of financial markets since the 1980s and the opening of new opportunities for investment, the financial sector has gained an increasing importance. This change has favoured the emergence of new actors (particularly institutional investors) that imposed new constraints on large Swiss companies by developing aggressive strategies to increase returns on the equity of their portfolio investments. Moreover, it also induced "traditional" actors (large banks notably) to change their preferences and strategies. The liberalisation of financial markets and the increasing influence of investors, emphasising financial liquidity, shareholder protection and accounting transparency, put increasing pressure on the Swiss corporate governance system. Its traditional functioning was affected on two dimensions: a profound change in the mechanisms of control of Swiss companies and the reform of the regulatory framework.

First, under the pressure of new institutional investors, a progressive disappearance of the traditional mechanisms of control among the largest Swiss companies from the end of the 1980s could be observed. Most large companies progressively abandoned their protectionist mechanisms (such as voting right distortions), through the simplification of their capital structure ${ }^{2}$. The sharp growth of market capitalisation (see Table 3 below) also indicates the increasing importance of stock markets as capital providers for companies, and a growing role of institutional investors in corporate control. We could also identify a clear breakdown of the Swiss intercompany network (interlocking directorates) during the 1990s (Schnyder et al. 2005). This is especially true for the traditionally close ties between large banks and non-financial companies. This change is related to the changing strategy of the largest Swiss banks, whose revenues increasingly stemmed from investment banking activities rather than traditional credit practices (see Schnyder et al. 2005). Second, and alongside the changing practices of the largest companies, the regulatory framework was profoundly reformed during the 1990s, with the reform of company law (1992) and the adoption of a new stock exchange law (1996). Even if these did not represent a brutal change and were the result of compromises between the decisive actors, the new regulations imposed changes in traditional corporate governance practices towards more transparency in disclosure rules and accounting presentation (Mach et al. 2007).

Changes in the mechanisms of control and the regulatory framework led to new strategies among the largest Swiss companies, which were much more exposed to the pressure of stock market evaluation and to the critical appreciation of institutional investors, focusing on the promotion of shareholder value. The sharp increase in the amount of profits redistributed to shareholders (through 
dividend payouts and share buybacks) was an important feature of the new strategic orientation of firms during the second half of the 1990s. The increase in mergers and acquisitions also resulted in huge mergers between some of the largest Swiss multinationals, threatened by potential foreign acquisitions: Ciba and Sandoz into Novartis in 1996, UBS and SBS in 1998, Crédit Suisse and Winthertur insurance in 1999. Many restructurings of major industrial companies also took place. These restructurings were generally motivated by the will to concentrate the activities of the companies on their core business and to abandon less profitable segments. This was the case for ABB, Sulzer or Algroup, some of the largest Swiss industrial firms, and also others in the chemical and pharmaceutical sector. These changes were completely in line with the advocates of a more "shareholder value" oriented strategy of the companies (for more details, Schnyder et al. 2005). With respect to the longstanding patterns mentioned above, it is also worth mentioning that some important Swiss companies are now controlled by foreign companies: this is the case for Swiss (the national airline company controlled by Lufthansa), Winterthur insurance, Sulzer, Algroup or Serono among the most well-known examples. At the same time, Swiss multinational companies saw a strong expansion abroad, which is illustrated by the sharp increase in the total outward FDI stocks during the 1990s (see Table 2 below).

- Tables 2 and 3 about here -

In Austria, the issues surrounding the debates on corporate governance have been different. The major topic has been the privatisation policy, since the mid1980s, of the large state-owned companies. Large Austrian companies are much less internationalised than their Swiss counterparts. This is mainly due to the central role of the state, which held controlling majorities of votes in most large firms (Kurzer 1993: 95), and thus prevented Austrian companies expanding abroad (see Table 2 on FDI). This central position of the Austrian state in the control and strategy of the largest companies goes back to the nationalisation Acts of 1946 and 1947. In 1989, the Austrian state was the largest domestic shareholder of the corporations listed on the stock exchange with 37.3\% (Gugler et al. 2001; Jud 1994: 473). The banking sector, which entertains close connections with Austrian governmental institutions, is another major actor in the corporate governance of large firms. Interlocking directorates are also very common in Austria as many executives of banks are represented on various supervisory boards (Jud 1994: 483ff). The predominance of the state was not challenged until the end of the 1980s. Since state-owned firms produced mainly raw materials and some heavy machinery, they posed no direct threat to small firms, dominated by family ownership, specialised in the production of consumer goods and politically close to the ÖVP. There was even a degree of 
complementarity, small firms being supplied by large ones in cheap energy, building materials, iron and steel, and essential equipment. For the socialdemocratic party and the trade unions, this system was a way of exerting control over Austrian industry (Kurzer 1993: 102-103). It is thus not surprising that, in contrast to Switzerland, employee representation has played an important role in Austria, organised along the lines of the German co-determination system (Jud 1994: 467).

Similarly to Switzerland, the concentration of ownership was particularly strong in Austria. By international standards, Austria seems to be the European country with the largest ownership concentration (Gugler et al. 2001). This concentration was strengthened by the existence of the state-owned holding (OIAG created in 1970), and the practice of "pyramiding" (mainly by banks) which allowed for the extension of control at a relatively low cost (Kurzer 1993: chap. 4; Gugler et al. 2001). In its heydays in 1975 , the OIAG group counted $120^{\prime} 000$ employees (approximately $18 \%$ of all persons employed in industry). Twenty years later, the situation had changed dramatically: in 1993, the state holding company has been transformed into a privatisation agency with the objective of relinquishing its majority stakes. The number of employees of the state holding fell to 4'800 as a result of the privatisation programme launched by the government during the 1990s. Even if efficiency increases in the privatised companies - especially after losses incurred by the nationalised industrial firms during the weak growth period of the 1980s - were officially mentioned as the main objective, another major reason for this extensive privatisation programme was to increase public revenues through sell-outs in order to reduce public deficits (Aiginger 1999; Nowotny 1998). In many ways, privatisations and the disappearance of the state holding represented a profound change in the Austrian corporate governance system. However, even if the maximising of revenue was a central criteria for choosing among the potential buyers, a second criteria was also introduced: the continuing operation in Austria of the privatised firms. The strategic goal was to keep these companies under Austrian influence and to make sure that headquarter functions and the resulting qualified employment opportunities would be located in Austria. For example, AMAG was sold in 1996 at a negative price to a joint venture consisting of the management and a large, private Austrian company. A kind of "national preference clause" was thus granted (Aiginger 1999: 265). In parallel to the privatisation programme and in the context of EU-membership, several regulatory reforms concerning financial markets and the stock exchange were also adopted during the 1990s. The main objectives of these new regulations were to favour the transparency of companies, to facilitate financial transactions and to promote the traditionally underdeveloped Austrian stock exchange.

Starting from a very different initial configuration (the presence of large multinational companies in Switzerland and the traditional dominance of nationalised state-owned companies in Austria), both countries followed a more 
liberal market driven policy in the field of corporate governance. This was made through a policy of privatisation and of state withdrawal from the major companies in Austria. In Switzerland, the changes were mainly the results of the changing strategies of the largest Swiss companies that progressively abandoned their traditional mechanisms of control in a new international economic context. Large companies have become much more transnationalised and subject to the pressure of financial markets, Austria to a much lesser extent than Switzerland.

Product market regulation has also been the subject of important reforms since the beginning of the 1990s; both countries followed liberalisation policies in order to promote competition on their domestic markets. In Austria, as a member of the EU, these liberalisation policies were mostly underpinned by the implementation of European directives, whereas in Switzerland, domestic impulses were more important. In both countries, the different indicators measuring the degree of product market regulations, distorting the functioning of competition, decreased substantially from the beginning of the 1990s.

Despite the emphasis usually put on its liberal character and openness, the exposure of the Swiss economy to international markets has been significantly mitigated by different measures, such as subsidies (for agriculture), public regulations or private cartels, all of which have facilitated non-competitive behaviour while protecting domestic markets from international competition. Several studies emphasised how almost two thirds of domestic prices were either administered, strongly regulated, or fixed by private cartels, which helped to explain the high level of domestic prices (Hauser \& Bradke 1992). Because of changes in the international environment during the early 1990s (GATT agreements and European economic integration), and because of internal demands to promote competition, heavy pressure was finally applied to a domestic sector increasingly regarded as a "rent-seeking", non-competitive, and structurally weak part of the economy. Because of the dual structure of its economy, characterised by the existence of "selective protectionist" mechanisms aimed at protecting domestic sectors, liberalisation policies in the domestic market took a particularly important place in Switzerland during the 1990s.

After the negative result of the referendum on entry into the EEA in December 1992, the government launched a programme of "economic revitalisation" whose main objective was to reduce production costs in the domestic sectors and enhance competition in the internal market; its leitmotiv was "Competitiveness abroad through increasing competition on domestic markets" (Mach 2006). One of the key elements of the revitalisation programme and inspired by European regulations were reforms of the "cartel law" in 1995 and 2003. Although the new law did not formally forbid cartels, it provided clearer guidelines and gave more power to antitrust authorities to combat anticompetitive practices. This reform faced strong opposition from the Small Business Association (USAM), that initially threatened to challenge the new law 
with a referendum but eventually accepted it. The revitalisation programme also included a new federal law on the internal market, which was expected to facilitate the free movement of goods, services, and persons on the Swiss territory, and thus to reduce market segmentation across cantons. Liberalisation measures also concerned the reform of agricultural policy and regulations of public procurement in the context of the GATT agreements. Such measures did generate some opposition among organised interests representing domestic economic sectors. Like all other European states, though with some delay, Switzerland also decided to liberalise its telecommunications sector (with a partial privatisation of the public operator) and, to a lesser extend, postal services before the first of January 1998, when the European directive on liberalising telecommunications came into force ${ }^{3}$. However, a first proposal to liberalise the electricity market was refused in a popular vote in 2002 , after an optional referendum launched by the trade unions and the social-democratic Party (for more details, Maggetti et al. 2010).

In Austria, the first state-owned companies that were privatised at the end of the 1980s were not natural monopolies in network industries, but touched mainly the manufacturing and banking sectors. With the adhesion to the EU in 1995 and the need to comply with its directives, further privatisation and liberalisation concerned telecommunications, postal services and electricity. The general competition legislation was also strengthened during the 2000s, with the creation of a new independent Federal competition authority in 2002.

\section{LABOUR MARKET AND INDUSTRIAL RELATIONS}

In Austria and Switzerland, labour market governance relies heavily on a system of cooperation between trade unions and employers, even if the extent of this coordination differs between the two countries: strong corporatism in Austria, and "lean" corporatism in Switzerland. By any standards, Austria is the corporatist country par excellence. It ranks first - ahead of Norway - in all 23 rankings of corporatism in the literature reviewed by Siaroff (1999: 184). Even in the case of collective bargaining at the sectoral level, organised interests are highly centralised, and the outcomes of bargaining apply to the whole economy. Switzerland, for its part, has been considered a more ambiguous case as regards its degree of corporatism, particularly in terms of centralisation of interest groups (more fragmented on the side of labour) and wage bargaining ${ }^{4}$.

Reflecting the different balance of power between business and labour in the two countries, the scope of public regulation of employment relationships is also less extensive in Switzerland than in Austria. Labour law in Switzerland has been mostly limited to issues of health and safety at work, leaving the central points of employment relationships to collective bargaining and collective labour agreement (CLAs); legal constraints on hiring and firing have been low in comparative perspective (see Becker, this volume, Table 1.6a). The degree of 
public regulation is somewhat higher in Austria, but collective bargaining is still the central regulation mode, which is reflected in the absence of a statutory minimum wage in both countries ${ }^{5}$. Social partners have traditionally played a predominant role in core areas such as wage-setting, the joint elaboration of governmental policy proposals, or vocational education. In this latter domain, both countries have a system of dual apprenticeship training (schooling and professional practice) involving both public authorities and companies. Similarly to Germany, the system of apprenticeship ensures a smooth transition between school and employment through the acquisition of specific skills, thereby ensuring low youth unemployment rates in comparative perspective (Culpepper 2007; Trampusch 2008a).

- Table 4 about here -

The Austrian system of industrial relations, built after the Second World War, is exceptional in many respects with regards to its structure and institutional anchorage. In its heyday in the 1960s, both prices and wages were coordinated in a corporatist fashion through the so-called parity commission, until price control lost its effectiveness in the late 1970s along with the increase in imports. It was only formally abandoned in 1994 (Traxler 1998: 246). Nowadays, despite the international (notably the entry in the EMU) and structural pressures that have challenged corporatism elsewhere in Europe, industrial relations in Austria have remained remarkably stable in recent decades, mainly thanks to deeply rooted institutional structures (Traxler 1998: 239). One of these central features is compulsory membership of all companies, farmers and wage earners in the system of Chambers, designed as official semi-public bodies of interest representation. On the employers' side, the Economic Chamber (WKO) and its regional affiliates have a monopoly of representation for all companies for both wage bargaining and consultation on draft legislation and administrative orders. On the workers' side, there is a division of tasks between the Chamber of Labour (BAK - Bundesarbeitskammer), who officially represents workers' interests in public policymaking, and the ÖGB (Österreichischer Gewerkschaftsbund) that takes part in collective bargaining. By contrast to the Arbeitskammer, membership in the ÖGB is not compulsory. The relations between them are based on an informal division of tasks rather than competition. Collective bargaining in Austria is conducted almost exclusively at the sectoral level, with a high level of coordination between sectors. The metalworking sector traditionally opens the bargaining round, and sets the standard for other sectors.

The statutory membership of all employers in the Economic Chamber is the main mechanism that explains the coverage rates approaching $100 \%$ that have persisted until now (EIRO 2005; Traxler 1998). Since all companies are members 
of the Economic chamber, they are all bound by the collective agreements negotiated by the peak organisation. This in turn extends to all workers independently if they are trade union members or not. Hence, even if union membership has declined steadily since the 1960s (see table 4), this has not had any effect on the level of coverage of collective bargaining. However, despite this institutional stability, the Austrian system is also faced with a trend of "organised decentralisation" whereby specific elements are shifted to lower bargaining levels to allow for more flexibility across firms (Traxler 1995). For instance, the WKO has recently been calling for the suppression of productivity as a key paysetting criterion in collective bargaining, and for the introduction of profitsharing schemes at the firm level instead, so that wage increases would be more closely linked to the performance of individual firms (EIRO 2008). Despite the high degree of coordination of the system, wage inequalities have also been fairly important across sectors, gender and employee status.

By contrast to the relative stability in collective bargaining, fairly radical changes have been observed in the influence of social partners in policymaking in Austria. As argued above, social partners (BAK and WKO) played a predominant role in the formulation of policies. They had a legal right to be consulted on any policy proposal through the Begutachtungsverfahren (consultation procedure). Policy deals were usually struck behind closed doors between the peak associations in close interaction with ruling parties, and Parliament was usually a mere rubberstamping institution for corporatist deals. In recent years, however, this system has been challenged by the erosion of the electoral base of the two traditional parties, and the emergence of new parties hostile to corporatism, notably the populist FPÖ and the Green party (Crepaz 1994; Traxler 1998: 258-259). The accession to power of a new "black and blue" (ÖVP/FPÖ) coalition in 2000 after nearly 30 years of social-democratic presence in Government has constituted a turning point in this process. Ruling parties have increasingly sought to bypass the veto power of social partners by marginalising them in policy procedures, and Parliament (as a locus of power for ruling parties rather than of social partners) seems to have gained in importance as an agenda-setting arena during this period (Obinger \& Talos 2006; Pelinka 2008). Many reforms inspired by a pro-market agenda have been brought forward against their will. Some of these reforms, notably in public pensions, were met by protest strikes, which partly accounts for the increase of industrial action in the 2000s (see table 4). Besides this, the corporatist system has been faced with increasing legitimacy problems reflected by declining membership. The influence of social partners, however, seems to have been restored with the return of a grand coalition in 2006 (Afonso 2010b).

In historical terms, Swiss industrial relations have displayed much more liberal features and a lesser degree of coordination than in Austria, notably with regard to the centralisation of wage bargaining (Fluder \& Hotz-Hart 1998: 274). Switzerland has been a contested case of corporatism precisely because of its 
fragmented organisational base. Traditionally, corporatism in Switzerland has been strong with regard to social partner involvement in policymaking and somewhat weak with regard to wage bargaining as such (Oesch 2007: 339). Even if the Swiss system of industrial relations can be considered a corporatist/coordinated model, it has always been a light/liberal variant of it from its early times of development. To some extent, it constituted a forerunner of what is now termed "competitive" or "supply-side" corporatism, in the sense that labour acquiescence has never been traded with expansionary economic policies, but rather with more immaterial compensations, like participation rights in policymaking (Traxler 2001). Industrial peace was presented as a sine qua non condition for competitiveness in a strongly export-oriented economy.

Collective bargaining in Switzerland also takes place essentially at the sectoral level, while some collective labour agreements are negotiated at the companylevel for big companies, like major retailers Migros and Coop. The coverage of collective bargaining is fairly low in comparative terms, and covers slightly less than half of the workforce (see table 4). Outcomes of collective bargaining may be extended beyond signing parties, and made legally enforceable by public authorities if they gather more than half of the workers and half of the companies in any given sector; this has traditionally been the case in the construction sector. Similarly to Austria, though in a much more informal way, the coordination of wages across economic sectors mainly takes place through highly organised sectoral employer organisations (under the umbrella of the peak level employer association, Schweizerische Arbeitgeberverband - SAV) (Oesch 2007: 338; Soskice 1990: 41). In Switzerland, the trade union movement has been much more fragmented along religious or occupational lines. In 2000, the biggest trade union Confederation, the Schweizerischer Gewerkschaftsbund (SGB), only gathered about $50 \%$ of all trade union members. Besides the SGB, there are a number of other smaller trade union confederations, notably for white-collar workers, the Christian federation CNG, or specific professions like teachers, police officers or nurses (Mach \& Oesch 2003: 164).

Despite its already fairly liberal nature, the Swiss system of industrial relations was challenged in the 1990s by the abrupt change in economic conditions outlined above, marked by economic stagnation and the rise of unemployment to unprecedented levels (Mach 2006). In some sectors, like the machine industry, employment shrank by a third, and by a quarter in construction. Until then, the Swiss labour market had remained virtually untouched by international crises due to the high level of flexibility in the labour supply provided by foreign workers (see above). During the 1980s, Switzerland was in a situation of full employment hardly found elsewhere in Europe. Things changed radically in the 1990s, when unemployment could no longer be "exported" due to the stabilisation of the legal situation of foreign workers, who were now entitled to unemployment benefits (Afonso 2005). Changing labour market conditions, but also international pressures on the Swiss economy, created opportunities for 
substantial changes in the Swiss system of industrial relations and labour market governance in general.

First, there was a decentralisation "offensive" by employers, who asked for substantial issues of collective bargaining to be shifted from the sectoral- to the company- or plant level. Between 1991 and 1996, the number of CLAs concluded at the firm level increased by $11.5 \%$, whereas the number of sectoral CLAs declined by $2.5 \%$. Since the late 1990 s wage setting and working time regulation has become decentralised to the company level of important industries such as chemicals, clothing, banking, media printing, and to a lesser extent, watchmaking (Mach \& Oesch 2003: 166). This furthers weakens the position of labour, also because work councils only play a marginal role in the Swiss economy. Second, besides changes in the level of bargaining, a certain number of changes also took place in its material content. On the one hand, automatic compensation of inflation was removed from many major sectoral agreements in the beginning of the 1990s. On the other, a growing number of CLAs provided for individual rather than general wages increases. This, combined with higher lowskilled unemployment, contributed not only to a great level of wage restraint in the 1990s, but also to a rise in wage inequalities. General wage increases have almost systematically been below inflation, so that actual real incomes have even declined during the decade. This has been especially the case for low-skilled workers, since individual wage increases mainly benefit skilled workers. These evolutions have, however, followed different paths across sectors, depending on the amount of skills required and their exposure to international competition (Mach \& Oesch 2003). On the trade union side, this changing environment has been met with new strategies, notably trade union mergers, an increase in industrial action or a more frequent resort to the political sphere (popular initiatives, referendums or legislative proposals) to compensate for losing ground in the sphere of collective bargaining (see for instance Trampusch 2008b; Widmer 2007).

With regard to the traditionally very important role of foreign labour, the old system of immigration quotas, that theoretically allowed public authorities to control the supply of foreign workers and adjust it to economic conditions was progressively abandoned for EU workers and replaced by free movement as part of a series of bilateral agreements with the EU (Afonso 2007; Fischer et al. 2002). This opening induced massive potential changes on the Swiss labour market due to persisting wage differentials between Switzerland and neighbouring countries. In order to prevent wage dumping, trade unions asked for a package of "flanking measures" involving the facilitated extension of collective bargaining, the possibility of introducing minimum wages and increased labour market control in the case of "observed abuse". This package was reluctantly accepted by employers' associations and right-wing parties. Hence, despite a decentralisation and de-regulation trend that started at the beginning of the 1990s, there has also been some extension of coordination later on in some economic sectors in relation to 
these "flanking measures". For instance, the number of collective agreements that have been extended and made legally binding by the state has increased in recent years. In the face of increased competition from EU member states, notably through the posting of workers, the protection of existing standards through legally binding CLAs, has been perceived by some employers, mainly in the construction sector, as a means to protect their market shares (Oesch 2007: 348).

There has also been evolution with regard to the other side of corporatism, namely social partner participation in policymaking. Corporatist policymaking seems to have been on the decline due to a number of factors: increased ideological polarisation also favoured by a more rightist composition of parliament, retrenchment pressures on the welfare state, the mediatisation of politics, the difficulties of traditional social partners to represent post-materialist values, such as gender equality (Häusermann et al. 2004). It has been more difficult for social partners to reach compromises on issues of social and economic policy, so that after the failure of corporatist talks, the reform of pensions or unemployment benefits have been ultimately struck in parliament rather than in corporatist arenas. On the other hand, social partners have played a central role in very important recent policymaking processes for the Swiss economy, such as the opening of the labour market for EU workers mentioned above (Afonso 2010). Contrary to Austria, the actual veto power given to interest groups by the institution of directed democracy has made it difficult to leave them aside, although patterns may vary across sectors and issues (see for instance Mach et al. 2003).

As a general picture, changes in the two countries in the sphere of industrial relations display diverging trends with regard to collective bargaining and participation in policy formulation. The already decentralised system of collective bargaining in Switzerland underwent a further decentralisation trend, whereas the highly coordinated Austrian system displayed relative continuity. On the other hand, whereas a right-wing coalition marginalised corporatist actors in policymaking in Austria, the veto power conferred to organised interests by direct democracy hampered this phenomenon in Switzerland, even if the capacity to strike corporatist deals has indeed been challenged.

\section{WELFARE STATE}

Both Austria and Switzerland display the ideal-typical characteristics of Bismarckian welfare states, namely eligibility conditioned by labour market participation, earnings-related benefits, a system of funding based on contributions on wages rather than taxes, and devolved and decentralised policy management (Häusermann 2009; Obinger \& Talos 2009). In both cases, its functioning tends to favour income compensation rather than redistribution as such, and the setting up of funding and benefits has been guided by a male breadwinner model. 
However, due to the differences in power configurations and institutional veto points outlined above, their welfare states have also displayed significant differences in their expansion and timing of development. On the one hand, because of the great number of veto points (mainly federalism and direct democracy) the Swiss welfare state has displayed an important delay vis-à-vis Austria with regard to the introduction of its core welfare programmes ${ }^{6}$. On the other hand, this institutional context has also slowed down retrenchment trends over the last two decades in Switzerland. By contrast, the welfare state in Austria has expanded more quickly, but has also recently undergone slightly more important changes because of the lighter institutional vetoes on policy change, as well as the advent of a new right-wing ruling coalition in 2000.

Just like in Germany, the first social security measures (in particular social assistance, unemployment benefits, pensions) were introduced in Austria in order to pacify an insurgent working class in the second half of the nineteenth century, under the Habsburg monarchy and in the interwar period (Obinger \& Talos 2006: 51ff.). During the Trente Glorieuses, the social security net underwent a considerable expansion under the influence of a progressive consensus between social democrats and conservatives, as well as a powerful labour movement: compulsory social protection included an ever greater proportion of workers, notably self-employed workers. The level of allowances also increased with the expansion of living standards. Between 1955 and 1985, social expenses increased from 15.9 percent to 27 percent of GDP. These measures not only included passive measures of protection but also active measures, such as active labour market policy, introduced in 1968 (Obinger \& Talos 2006: 53). By international standards, Austria has displayed an above-average level of social spending over the twentieth century.

The trajectory of welfare state expansion in Switzerland has been significantly different. First, decentralised political structures and the power of business interests opposed to state intervention have fostered a fragmented, heterogeneous and layered system of social protection mixing private, public and semi-public service providers: private companies, trade unions, communes and cantons. Welfare state expansion has rather been a "pragmatic bricolage" of different existing social protection schemes rather than a real "government masterplan" (Häusermann 2009: 2; see also Leimgruber 2008). Until 1945, federal money was only spent in the form of subsidies to those different kinds of institutions in the domain of health, accident and unemployment. As argued above, the transfer of competences from cantons to the federal state was faced with the constraints set by federalism and direct democracy, so that the establishment of a nation-wide system of welfare provision has been very difficult to achieve (Obinger 1998) ${ }^{7}$. Several measures of expansion have been refused by a majority of citizens in referendums over the twentieth century (see for instance for health insurance Immergut 1992). A major difference between Austria and Switzerland has also been the balance between public, semi-public 
and private carriers of social protection. This difference is especially observable in the domains of pensions and health: whereas about $80 \%$ of the Swiss workforce was covered by occupational pension plans in 2000 , this proportion was only about $16 \%$ in Austria (Url 2003). The Swiss "three-pillar" system, that combines a system of pay-as-you-go public pensions, occupational pensions based on capitalisation and optional individual savings accounts, has been praised as the way to follow for many countries (Leimgruber 2008). Health insurance in Switzerland is also exclusively carried out by private companies, and contribution levels are not based on incomes; low incomes received public subsidies. Accordingly, the Swiss welfare state is one of the least redistributive in the OECD, inclusive of the liberal states (Iversen \& Stephens 2008: 603see also (Häusermann 2009).

\section{- Table 5 about here -}

If the institutional framework has influenced the patterns of development of the welfare state, it has also conditioned patterns of continuity and change over the last two decades. Hence, the extent of changes can be considered more important in Austria than in Switzerland, even if the direction of changes has shown many similarities. As elsewhere, the ageing of societies, transformations in the structure of employment and financial difficulties have put welfare states under pressure for reform. Faced with rising public deficits and debts caused by problems in large parts of state-owned industries in the mid-1980s, the SPÖ/ÖVP coalition that came to power in 1987 implemented a programme of cost containment that resulted in several measures of welfare retrenchment (for instance in eligibility for early retirement) and increased contributions (Obinger \& Talos 2009: 9). In labour market policy, a combination of benefit cutbacks and increased control over the unemployed towards activation was put in place. Besides these retrenchment measures, however, a series of new benefits in care or health insurance were introduced, and the Austrian welfare state did not depart from its central characteristics during this period. The real breakthrough may have come in $\mathbf{2 0 0 0}$ with the accession to power of the right-wing ÖVP/FPÖ coalition, that carried out a series of reforms along a neoliberal agenda, that is, a paradigm shift with regard to Austrian "social corporatism". A series of cutbacks in unemployment benefits (lower replacement rate, end of adaptation of benefits to inflation and wages) was carried out. A contested reform of pensions providing for the abolition of early retirement schemes and an increased length of contribution was met by the largest strike movement in Austrian history. Interestingly, in the long run, the aim was to depart from a pay-as-you-go system and move more towards a three-pillar system as found in Switzerland. These reforms were met with considerable protest from trade unions in 2003, especially because the new coalition tried to implement the reforms by 
bypassing the traditional role of social partners in social policies (Obinger \& Talos 2006). In sum, a series of retrenchment measures did take place in Austria, which is reflected to some extent in the evolution of social expenditures that slightly decreased between 1995 and 2003 (see table 5).

Even though it was faced with fairly similar challenges, the Swiss welfare state did not undergo such radical changes as early as in Austria, at least in terms of retrenchment. On the economic side, Switzerland was not faced with major disturbances on the labour market until the beginning of the 1990s, so that major pressures for welfare state reform came later than in most other countries. Besides this, because of its late institutionalisation, the costs of welfare were still at a low level by international standards when the Swiss economy was hit by economic unrest in the 1990s (Häusermann 2009). On the political side, even though a number of reforms have been implemented, rapid retrenchment measures have been slowed down by the many veto points of the political system (especially the optional referendum, which allows opponents to call for a popular vote on any reform adopted by Parliament), and change has tended to be of an incremental nature. Interestingly, while the referendum was used by conservative political forces to oppose welfare state expansion up to the 1980s, it has since been used by social democrats and trade unions to oppose its cutback in the 1990s and 2000s. Direct democracy implies a strong political bias towards the status quo.

In general, reform dynamics have been guided by retrenchment and financial consolidation on the one hand, and recalibration to take into account new social needs and demands on the other (Häusermann 2009). In many reforms, given the veto institutional constraints outlined above, recalibration (valued by the left and progressive strands within the right) has been used as a quid-pro-quo for retrenchment (championed by the conservative right) (Bonoli 1999; Häusermann et al. 2004). However, patterns of change have varied across areas of social protection. In pensions, an important reform was achieved in the mid-90s that provided for an increase in the age of retirement for women, but also a "splitting system" whereby the contributions of both spouses would be added, divided by two and counted separately, as well as pension credits for mothers. Both measures improved the benefits of women, especially non-working women. The last attempt at reform, that included unilateral retrenchment measures, such as cutbacks for widows or a further rise in women's retirement age, was rejected in a popular referendum in 2003. In unemployment insurance, a series of urgent measures were carried out by decree in the 1990s to cope with the important increase in unemployment: the maximum period of entitlement was increased to two years, but the replacement rate was lowered from 80 to $70 \%$. Another important reform introduced a set of activation measures whereby resources devoted to active labour market policies were multiplied by 6; on the other hand, increased control and possible sanctions were introduced towards the unemployed not "actively seeking work" (Bertozzi et al. 2005). In 2002, citizens 
accepted another reform providing for a toughening of conditions of entitlement and a shortening of the maximum period of allowances (Afonso 2010). In general, it has proven easier to carry out retrenchment in domains that concern a fringe of the population, like unemployment or disability policy, than in pensions, where cuts potentially affect everyone. Partly because existing schemes were so weakly developed in comparison with other countries, expansion measures have been achieved in family policy, with the introduction of a maternity insurance in 2005, and a harmonisation of family allowances in 2006. Confronted with important cost increases, the domain of health insurance has been a constant issue of debates over the last decade, and has remained in a deadlock so far. Both attempts to increase the role of the state and restrict reimbursements have been refused so far.

Generally speaking, the constraining institutional framework in Switzerland has fostered more incremental reforms than in Austria, especially when the latter was governed by a right-wing coalition from 2000 to 2006. It must be kept in mind, however, that Swiss welfare programmes have remained at a lower level in terms of the array of social risks covered by law. In some ways, the wider heterogeneity of welfare provision (private/public mix) has also fostered a more flexible evolution because of the wider array of tools available, and an already greater importance of market-based schemes of social provision. As argued above, the Swiss "three-pillar" pension system (combining public, occupational and private schemes) has been considered - at least until the 2008 financial crisis - more ready for population ageing than strictly public schemes like the Austrian one (Leimgruber 2008). On the other hand, the great fragmentation of welfare provision, for instance in the domain of health, has led to lower costs in Austria than in Switzerland, where both the overall cost of the health system and the individual cost burden for patients is among the highest in the OECD.

\section{CONCLUSION}

Patterns of change and continuity in the Austrian and Swiss varieties of capitalism display an overall trend towards a more market-driven orientation, but prevailing institutional and coalitional determinants have strongly influenced the extent and direction of change across the different spheres of economic governance (industrial relations, corporate governance, welfare state). The trajectory and scope of change vary both between the countries and between the spheres, depending on the interaction between power configurations and the institutional regimes governing the different spheres. With its weak trade unions, strong business, and lean welfare state, the Swiss political economy seemed generally more readily adaptable to the constraints of a new international environment focusing on markets as the dominant mode of regulation. However, if change has been fairly swift in domains where private employer governance was the dominant mode of regulation, such as corporate 
governance and industrial relations, pressures for change have been faced with powerful institutional barriers (most notably direct democracy) in domains where institutional change required political intervention. In Austria, by way of contrast, the extensive role of the state in the political economy has made political intervention more important in triggering economic change, whereas the nature of the power configuration within private organised interests was not particularly favourable to enhanced market solutions. In Switzerland, substantial change still essentially takes place through private employer coordination, whereas in Austria change is mainly triggered by public intervention, as shown by the scope of welfare state reforms carried out by the conservative coalition that came to power in 2000 (Obinger and Talos 2006).

- Table 6 over here -

In the framework adopted here, longstanding institutional arrangements and power configurations continue to determine continuity and change both at the macro- and sectoral-level. The constant defiance of Swiss dominant economic interests towards state intervention has favoured a relatively high level of private flexibility in the face of changing economic conditions. On the other hand, to the extent that public decisions are needed, Austria has probably displayed a higher reform capacity, for better or for worse. In this respect, longstanding distributions of power to public and private actors continue to determine patterns of continuity and change in their varieties of capitalism.

\section{REFERENCES}

Afonso, A. (2005) "When the Export of Social Problems is No Longer Possible: Immigration Policies and Unemployment in Switzerland", Social Policy \& Administration 39(6): 653-668.

- - - (2007) "Policy Change and the Politics of Expertise. Economic Ideas and Immigration Control Reforms in Switzerland", Swiss Political Science Review 13(1): 1-38.

- - - (2010) "Europeanisation, Policy Concertation and New Political Cleavages: The Case of Switzerland", European Journal of Industrial Relations 16(1): 57-72.

Aiginger, K. (1999) "The Privatization Experiment in Austria", Austrian Economic Quarterly 4(1): 261-270.

Armingeon, K., M. Gerber, P. Leimgruber, and M. Beyeler (2007) Comparative Political Data Set 1960-2006. Bern: Institute of Political Science, University of Berne.

Bertozzi, F., G. Bonoli, and B. Gay-des-Combes (2005) La réforme de l'Etat social en Suisse. Vieillissement, emploi, conflit Travail-Famille. Lausanne: PPUR. 
Bonoli, G. (1999) "La réforme de l'Etat social suisse: Contraintes institutionnelles et opportunités de changement", Revue Suisse de Science Politique 5(3): 57-77.

Bonoli, G., and A. Mach. (2000) "Switzerland: Adjustment Politics Within Institutional Constraints" in Scharpf, F.W., and V. Schmidt (eds.) Welfare and Work in the Open Economy. Oxford: Oxford University Press: 131-173.

Crepaz, M. (1994) "From Semi-sovereignty to Sovereignty. The Decline of Corporatism and Rise of Parliament in Austria", Comparative Politics 27(1): 45-65.

Culpepper, P. (2007) "Small States and Skill Specificity: Austria, Switzerland, and Interemployer Cleavages in Coordinated Capitalism", Comparative Political Studies 40(6): 611.

David, T., and A. Mach. (2004) "The Specificity of Corporate Governance in Small States: Institutionalisation and Questioning of Ownership Restrictions in Switzerland and Sweden" in R., A., and F. M. (eds.) Corporate Governance in a Changing Economic and Political Environment. Trajectories of Institutional Change on the European Continent. London: Palgrave: 220-246.

Eiro (2005) "Austria: Industrial Relations Profile", European Industrial relations observatory online

- - (2007) "Austria: Social Partners Agree to Minimum Wage Increase", European industrial relations observatory online 2007(7):

- - (2008) "Austria: Wage Flexibility and Collective Bargaining", European Industrial relations observatory online 2008(3):

Fischer, A., S. Nicolet, and P. Sciarini (2002) "Europeanisation of Non-EU Countries: The Case of Swiss Immigration Policy Towards the Eu", West European Politics 25(4): 143-170.

Fluckiger, Y. (1998) "The Labour Market in Switzerland: The End of a Special Case?", International Journal of Manpower 19(6): 369-395.

Fluder, R., and B. Hotz-Hart. (1998) "Switzerland: Still as Smooth as Clockwork?" in Ferner, A., and R. Hyman (eds.) Changing Industrial Relations in Europe. Oxford: Blackwell: 262-281.

Gugler, K., S. Kalss, A. Stomper, and J. Zechner. (2001) "The Separation of Ownership and Control in Austria" in Barca, F., and M. Becht (eds.) The Control of Corporate Europe. Oxford: Oxford University Press: 46-70.

Hall, P. A., and D. Soskice (2001) Varieties of Capitalism : The Institutional Foundations of Comparative Advantage. Oxford [England] ; New York: Oxford University Press.

Hauser, H., and S. Bradke (1992) EWR-Vertrag, EG-Beitritt, Alleingang Wirtschaftliche Konsequenzen für die Schweiz. Gutachten zu Handen des Bundesrates. Chur Zürich: Rüegger.

Häusermann, S. (2009) "Reform Opportunities in a Bismarckian Latecomer: Restructuring the Swiss Welfare State" in Palier, B. (ed.) A Long Good-Bye 
to Bismarck? The Politics of Welfare Reform in Continental Europe. Amsterdam: Amsterdam University Press:

Häusermann, S., A. Mach, and Y. Papadopoulos (2004) "Social Policy Making Under Strain in Switzerland", Swiss Political Science Review 10(2): 33-59.

Hemerijck, A., B. Unger, and J. Visser. (2000) "How Small Countries Negotiate Change: Twenty-Five Years of Policy Adjustment in Austria, the Netherlands, and Belgium" in Scharpf, F.W., and V.A. Schmidt (ed.) Welfare and Work in the Open Economy. Volume li: Diverse Responses to Common Challenges. Oxford: Oxford University Press:

Immergut, E. M. (1992) Health Politics : Interests and Institutions in Western Europe. Cambridge: Cambridge University Press.

Iversen, T., and J. Stephens (2008) "Partisan Politics, the Welfare State, and Three Worlds of Human Capital Formation", Comparative Political Studies 41(4/5): 600-637.

Jud, W. (1994) "Institutional Investors and Corporate Governance: The Austrian View" in Baums, T. (ed.) Institutional investors and corporate governance. Berlin: 465-488.

Katzenstein, P. J. (1984) Corporatism and Change: Austria, Switzerland, and the Politics of Industry. Ithaca ; London: Cornell University Press.

- - - (1985) Small States in World Markets: Industrial Policy in Europe. Ithaca, NY: Cornell University Press.

Kurzer, P. (1993) Business and Banking : Political Change and Economic Integration in Western Europe. Ithaca: Cornell University Press.

Leimgruber, M. (2008) Solidarity Without the State? : Business and the Shaping of the Swiss Welfare State, 1890-2000. Cambridge: Cambridge University Press.

Lijphart, A. (1999) Patterns of Democracy : Government Forms and Performance in Thirty-Six Countries. New Haven: Yale University Press.

Mach, A., and D. Oesch (2003) "Collective Bargaining Between Decentralization and Stability: A Sectoral Model Explaining the Swiss Experience During the 1990s", Industrielle Beziehungen 10(1): 160-182.

Mach, A. (2006) La Suisse entre internationalisation et changements politiques internes. Les relations industrielles et la législation sur les cartels dans les années 1990. Chur: Ruegger.

Mach, A., S. Häusermann, and Y. Papadopoulos (2003) "Economic Regulatory Reforms in Switzerland: Adjustment Without European Integration, Or How Rigidities Become Flexible", Journal of European Public Policy 10(2): 301318.

Mach, A., G. Schnyder, T. David, and M. Lüpold (2007) "Transformations of SelfRegulation and New Public Regulations in the Field of Swiss Corporate Governance (1985-2002)", World Political Science Review 3(2): 1-30. 
Merrien, F.-X., and U. Becker. (2005) "The Swiss Miracle : Low Growth and High Employment" in Becker, U., and H. Schwartz (eds.) Employment Miracles. Amsterdam: Amsterdam University Press: PAGE?

Nowotny, E. (1998) "Privatisation, Deregulation, Reregulation - Experiences and Policy Issues in Austria", Journal for Institutional Innovation, Development, and Transition 235-48.

Obinger, H. (1998) "Federalism, Direct Democracy, and Welfare State Development in Switzerland", Journal of Public Policy 18(03): 241-263.

Obinger, H., and E. Talos (2009) "Janus-Faced Developments in a Prototypical Bismarckian Welfare State. Welfare Reforms in Austria Since the 1970s" in Palier, B. (ed.) A Long Good-Bye to Bismarck? The Politics of Welfare Reform in Continental Europe. Amsterdam: Amsterdam University Press:

- - (2006) Sozialstaat Österreich zwischen Kontinuität und Umbau. Eine Bilanz der Övp/Fpö/Bzö Koalition. Wiesbaden: VS Verlag für Sozialwissenschaften.

Oesch, D. (2007) "Weniger Koordination, mehr Markt? Kollektive Arbeitsbeziehungen und Neokorporatismus in der Schweiz seit 1990", Swiss Political Science Review 13(3): 337-368.

Pelinka, A. (2008) "Gesetzgebung Im Politischen System Österreichs" in Ismayr, W. (ed.) Gesetzgebung in den Staaten der Europäischen Union. Wiesbaden: VS Verlag für Sozialwissenschaften: 431-462.

Piotet, G. (1987) Restructuration et corporatisme. Le cas de I'horlogerie en Suisse, 1974-1987. Lausanne: Imprivite SA.

Schnyder, G., M. Lüpold, A. Mach, and T. David (2005) The Rise and Decline of the Swiss Company Network During the 20th Century. Lausanne: Travaux de Science Politique 22.

Schröter, H.G. (1999) "Small European Nations: Cooperative Capitalism in the Twentieth Century" in Chandler, A.D., F. Amatori, and T. Hikino (eds.) Big Business and the Wealth of Nations. Cambridge: Cambridge University Press: 176-204.

Siaroff, A. (1999) "Corporatism in 24 Industrial Democracies: Meaning and Measurement", European Journal of Political Research 36(6): 175-205.

Soskice, D. (1990) "Wage Determination: The Changing Role of Institutions in Advanced Industrialized Countries", Oxford Review of Economic Policy 6(4): 36-61.

Trampusch, C. (2008a) "Employers, the State, Trade Unions and the Politics of Institutional Change. Varieties of Institutional Change in the Vocational Education and Training Regimes in Austria, Germany and Switzerland", Gemeinsame Tagung von DVPW, ÖGPW und SVPW "Die Verfassung von Demokratien", 21.-23.11.2008

- - (2008b) "Von einem liberalen zu einem Post-liberalen Wohlfahrtsstaat. Der Wandel der gewerkschaftlichen Sozialpolitik in der Schweiz", Swiss Political Science Review 14(1): 49-84. 
Traxler, F. (1995) "From Demand-Side to Supply-Side Corporatism? Austria's Labour Relations and Public Policy" in Crouch, C., and F. Traxler (eds.) Organized Industrial Relations in Europe: What Future. Aldershot: Ashgate: 271-286.

- - - (1998) "Austria: Still the Country of Corporatism" in Ferner, A., and R. Hyman (eds.) Changing Industrial Relations in Europe. Oxford: Blackwell: 239-261.

- - - (2001) "Die Metamorphosen des Korporatismus: Vom Klassischen zum Schlanken Muster", Politische Vierteljahresschrift 42(4): 590-623.

Url, T. (2003) "Occupational Pension Schemes in Austria", Austrian Economic Quarterly 2003(2): 64-70.

Visser, J. (2009) Ictwss: Database on Institutional Characteristics of Trade Unions, Wage Setting, State Intervention and Social Pacts in 34 Countries Between 1960 and 2007. Amsterdam: Amsterdam Institute for Advanced labour Studies.

Widmer, F. (2007) "Stratégies syndicales et renouvellement des élites: Le Syndicat FTMH face à la crise des années 1990", Swiss Political Science Review 13(3): 395-431. 
Table 1: Macro-economic performance

\begin{tabular}{|c|c|c|c|c|c|c|}
\cline { 2 - 7 } \multicolumn{1}{c|}{} & \multicolumn{3}{c|}{ Austria } & \multicolumn{3}{c|}{ Switzerland } \\
\hline & 1980s & 1990s & 2000s & 1980s & 1990s & 2000s \\
\hline 1. Real GDP Growth & 2.0 & 2.7 & 2.0 & 2.3 & 1.1 & 1.9 \\
\hline \begin{tabular}{c} 
2. Inflation \\
\hline $\begin{array}{c}\text { 1. Employment ratio } \\
\text { (\%) }\end{array}$
\end{tabular} & 3.8 & 2.4 & 2.0 & 3.3 & 2.3 & 1.0 \\
\hline $\begin{array}{c}\text { 2. Unemployment } \\
\text { (\%) }\end{array}$ & 3.3 & 3.8 & 4.4 & 0.6 & 3.0 & 3.5 \\
\hline
\end{tabular}

Sources: Armingeon et al. (2007)

Table 2: Outward and Inward Foreign Direct Investment Stocks, 1985-2007 (\% of GDP)

\begin{tabular}{|l|c|c|c|c|c|c|c|c|c|c|}
\hline & \multicolumn{2}{|c|}{1985} & \multicolumn{2}{c|}{1990} & \multicolumn{2}{c|}{1995} & \multicolumn{2}{c|}{2000} & \multicolumn{2}{c|}{2007} \\
\hline & Out & In & Out & In & Out & In & Out & In & Out & In \\
\hline Austria & 2.0 & 5.7 & 2.7 & 6.2 & 5.1 & 7.6 & 12.9 & 15.7 & 34.0 & 34.0 \\
\hline Switzerland & 27.0 & 10.8 & 28.9 & 15.0 & 46.3 & 18.6 & 92.9 & 34.7 & 142.6 & 65.7 \\
\hline
\end{tabular}

Source: UNCTAD 2008. World Investment Report.

Table 3 Evolution of market capitalisation 1975-2005 (\% of GDP)

\begin{tabular}{|l|c|c|c|c|c|c|c|c|c|c|}
\hline & 1975 & 1980 & 1985 & 1990 & 1995 & 1996 & 1997 & 1998 & 2000 & 2005 \\
\hline Austria & 9 & 3 & 7 & 17 & 14 & 15 & 18 & 17 & 14 & 41 \\
\hline Switzerland & 30 & 42 & 91 & 69 & 130 & 136 & 225 & 260 & 322 & 256 \\
\hline
\end{tabular}

Source: OECD Financial market trends (various issues) 
Table 4 Labour market and wage bargaining indicators (decade averages)

\begin{tabular}{|c|c|c|c|c|c|c|}
\cline { 2 - 7 } \multicolumn{1}{c|}{} & \multicolumn{3}{c|}{ Austria } & \multicolumn{3}{c|}{ Switzerland } \\
\hline & 1980s & 1990s & 2000s & 1980s & 1990s & 2000s \\
\hline $\begin{array}{c}\text { 1. Coverage of } \\
\text { collective bargaining } \\
\text { (\%) }\end{array}$ & 96.0 & 99.0 & 99.0 & 50.0 & 47.4 & 44.8 \\
\hline $\begin{array}{c}\text { 2. Trade union } \\
\text { density (\%) }\end{array}$ & 52.1 & 41.7 & 34.4 & 27.9 & 22.6 & 20.0 \\
\hline $\begin{array}{c}\text { 3. Centralisation of } \\
\text { wage bargaining } \\
\text { index (0-1) }\end{array}$ & 0.917 & 0.895 & 0.777 & 0.385 & 0.392 & 0.409 \\
\hline $\begin{array}{c}\text { 4. Index of strike } \\
\text { activity (working } \\
\text { days lost per 1000 } \\
\text { workers) }\end{array}$ & 2.0 & 3.5 & 50.0 & 0.4 & 1.4 & 3.4 \\
\hline
\end{tabular}

Source: 1-3: Visser (2009)4: own calculations based on Armingeon et al. (2007)

Table 5: Social expenditures as a percentage of GDP

\begin{tabular}{|c|c|c|c|c|c|c|}
\hline & \multicolumn{3}{|c|}{ Austria } & \multicolumn{3}{c|}{ Switzerland } \\
\hline & 1985 & 1995 & 2003 & 1985 & 1995 & 2003 \\
\hline Total public social expenditures & 23.9 & 26.6 & 26.1 & 14.8 & 17.5 & 20.5 \\
\hline Pensions & 11.0 & 12.3 & 12.8 & 5.8 & 6.5 & 6.8 \\
\hline Health & 4.9 & 5.9 & 5.1 & 3.9 & 4.7 & 6.0 \\
\hline Family policy & 2.9 & 3.1 & 3.1 & 1.0 & 1.2 & 1.5 \\
\hline Incapacity Benefits & 2.8 & 2.8 & 2.6 & 2.2 & 2.5 & 3.3 \\
\hline $\begin{array}{c}\text { Unemployment: passive } \\
\text { measures }\end{array}$ & 0.9 & 1.3 & 1.0 & 0.3 & 1.1 & 1.0 \\
\hline Unemployment: active measures & 0.3 & 0.4 & 0.6 & 0.2 & 0.5 & 0.7 \\
\hline
\end{tabular}

Source: Armingeon et al. (2007) 
Table 6: Summary of continuity and change

\begin{tabular}{|c|c|c|}
\hline & AUSTRIA & SWITZERLAND \\
\hline $\begin{array}{l}\text { Political framework } \\
\text { and power } \\
\text { relationships }\end{array}$ & $\begin{array}{l}\text { Centralised federalism } \\
\text { Employers dominated by } \\
\text { SMEs, strong labour } \\
\text { Policy capacity dependent on } \\
\text { coalitions }\end{array}$ & $\begin{array}{l}\text { Decentralised federalism } \\
\text { Strong export-oriented business, } \\
\text { weak labour } \\
\text { Policy capacity constrained by } \\
\text { various institutional veto points }\end{array}$ \\
\hline $\begin{array}{l}\text { Corporate } \\
\text { governance } \\
\text { economic } \\
\text { regulation }\end{array}$ & $\begin{array}{l}\text { Important changes in } \\
\text { corporate control through } \\
\text { privatisation and liberalisation, } \\
\text { especially since EU-adhesion } \\
\text { Promotion of competition }\end{array}$ & $\begin{array}{l}\text { Important changes in corporate } \\
\text { control, market-driven reforms of } \\
\text { corporate governance } \\
\text { New public regulations to } \\
\text { promote competition }\end{array}$ \\
\hline $\begin{array}{l}\text { Industrial relations } \\
\text { and labour market }\end{array}$ & $\begin{array}{l}\text { Continuity in collective } \\
\text { bargaining despite organised } \\
\text { decentralisation } \\
\text { Marginalisation trend of social } \\
\text { partners in policymaking }\end{array}$ & $\begin{array}{l}\text { Decentralisation trend } \\
\text { No marginalisation due to veto } \\
\text { power conferred by direct } \\
\text { democracy, but declining capacity } \\
\text { to strike deals. }\end{array}$ \\
\hline Welfare state & $\begin{array}{l}\text { Acceleration of retrenchment } \\
\text { reforms under black-blue } \\
\text { coalition }\end{array}$ & $\begin{array}{l}\text { Retrenchment hindered in some } \\
\text { domains by direct democracy; } \\
\text { recalibration }\end{array}$ \\
\hline
\end{tabular}

\section{NOTES}

${ }^{1}$ For useful comments on the chapter, we are very thankful to Uwe Becker, Pepper Culpepper, Silja Häusermann, Hanspeter Kriesi, Daniel Oesch, Yannis Papadopoulos, Raphael Ramuz and Christine Trampusch. Alexandre Afonso acknowledges the financial support of the NCCR Democracy and the Swiss National Fund for Scientific Research, as well as the Amsterdam Institute for Advanced Labour Studies of the University of Amsterdam.

2 The largest companies introduced a "single share", which reduces the possibility to control the composition of the shareholders. In 1989, only $13.1 \%$ of the companies listed at the Stock Exchange had a 'single share'; in 2001, this proportion reached 70.7 per cent (out of 198 companies). This does not mean, however, the end of family ownership and the victory of minority shareholders. There are still other measures, which allow Swiss corporations to channel the 
evolution of their shareholding structure: they may fix ceilings for voting rights at shareholders' meetings or introduce a percentage limit for each individual shareholding.

${ }^{3}$ The Swiss Confederation remains, however, the majority owner in Swisscom (the biggest phone and internet provider) and in Swiss Post.

${ }^{4}$ In Siaroff's (1999) indicator of corporatism termed " integration " understood as "a long-term co-operative pattern of shared economic management involving the social partners and existing at various levels such as plant-level management, sectoral wage bargaining, and joint shaping of national policies in competitiveness-related matters (education, social policy, etc.)", Austria ranked first with 4.625 out of 5 , whereas Switzerland ranked $7^{\text {th }}$ with 4.375 in the mid 1990s.

${ }^{5}$ However, an agreement on an intersectoral minimum wage has been reached by Austrian social partners in 2007 (EIRO 2007).

6 For example: accident insurance (1888 in Austria vs. 1918 in Switzerland), mandatory unemployment insurance (1920 vs. 1982), old age pensions (1927 vs. 1948), mandatory health insurance (1955 vs. 1994) or maternity insurance (1955 vs. 2005; Obinger and Talos 2008, 51ff; Leimgruber 2008, 5).

${ }^{7}$ The time gap between the adoption of a constitutional principle and its coming into effect into a law has been extremely large: 106 years for health insurance (1890 vs. 1996), 60 years for maternity insurance (1945 vs. 2005) and 23 years for state pensions (1925 vs. 1948) (Häusermann 2009). 